\title{
Evaluasi Manajemen Pengelolaan Obatdi Instalasi Farmasi Rumah Sakit Tipe C Se-Kabupaten Tegal Tahun 2021
}

\author{
Tiara Fany Safitri ${ }^{1 *}$, Yulian Wahyu Permadi ${ }^{2}$, Wulan Agustin Ningrum ${ }^{3}$, St. \\ Rahmatullah4 \\ ${ }_{1,2,3,4}$ Prodi Sarjana Farmasi, Universitas Muhammadiyah Pekajangan Pekalongan, Indonesia \\ *email: trfnysftr@gmail.com
}

\begin{abstract}
Drug logistics management plays an important role in improving pharmaceutical services in hospital pharmacy installations and is one of the aspects to determine the success of rational treatment programs in hospitals. This study aims to determine the implementation of pharmaceutical preparation service standards in accordance with the Technical Guidelines for Pharmaceutical Services Standards in Hospitals in 2019. The method used in this study is descriptive using a total sampling technique of 42 respondents with an average age of 26-35 years. who are female and male with the last education of the pharmacist profession. The results of the evaluation of this study are that the management of drug logistics in type $C$ hospitals throughout Tegal Regency in the process of selecting, receiving, storing, distributing and controlling is appropriate $(100 \%)$, planning needs according to $(90.5 \%)$, destruction according to $(97,6 \%)$ and administration in accordance with $(81 \%)$ Technical Guidelines for Pharmaceutical Services Standards in Hospitals in 2019
\end{abstract}

Keywords: Management; Drug Logistics; Evaluation

\begin{abstract}
Abstrak
Manajemen pengelolaan logistic obat sangatlah berperan penting dalam meningkatkan pelayanan kefarmasian di Instalasi farmasi rumah sakit dan salah satu aspek untuk menentukan suksesnya program pengobatan secara rasional di Rumah Sakit. Penelitian ini bertujuan untuk mengetahui pelaksanaan standard pelayanan pengelolaan sediaan farmasi yang sesuai dengan Petunjuk Teknis Standar Pelayanan Kefarmasian Di Rumah Sakit Tahun 2019. Metode yang digunakan dalam penelitian ini bersifat deskriptif dengan menggunakan teknik total sampling sebanyak 42 responden dengan rata-rata berusia 26-35 tahun yang berjenis kelamin perempuan dan laki-laki dengan berpendidikan terakhir profesi apoteker. Hasil evaluasi dari penelitian ini bahwa pengelolaan logistic obat di rumah sakit tipe $\mathrm{C}$ seKabupaten Tegal dalam proses pemilihan, penerimaan, penyimpanan, pendistribusian dan pengendaliansesuai $(100 \%)$, perencanaan kebutuhan sesuai $(90,5 \%)$, pemusnahan sesuai (97,6\%) dan administrasi sesuai (81\%) Petunjuk Teknis Standar Pelayanan Kefarmasian di Rumah Sakit Tahun 2019.
\end{abstract}

Kata kunci: Manajemen; Logistik Obat; Evaluasi

\section{Pendahuluan}

Rumah sakit adalah institusi pelayanan kesehatan yang menyelenggarakan pelayanan kesehatan seseorang secara paripurna yang menyediakan pelayanan rawat inap, rawat jalan dan gawat darurat. Upaya kesehatan bermanfaat memelihara dan meningkatkan kesehatan serta tempat yang dipakai untuk kegiatan disebut sebagai sarana kesehatan. Sarana kesehatan berfungsi buat melakukan upaya kesehatan dasar atau upaya penunjang kesehatan. Selain itu, sarana kesehatan bisa juga digunakan buat kepentingan pendidikan, training dan penelitian pengembangan ilmu 


\section{Prosiding Seminar Nasional Kesehatan Lembaga Penelitian dan Pengabdian Masyarakat Universitas Muhammadiyah Pekajangan Pekalongan}

pengetahuan teknologi dibidang kesehatan. Salah satu sarana kesehatan yang menyelenggarakan upaya kesehatan rumah sakit (Permenkes, 2016)

Pelayanan kesehatan di rumah sakit berdekatan dengan penggunaan perbekalan farmasi yang terdiri dariobat-obatan, bahan kimia, bahan radiologi, alat kesehatan habis pakai, alat-alat kedokteran dan gas medik. Selain itu pemasukkan rumah sakit yang berasal dari pengelolaan perbekalan farmasi adalah sekitar $50 \%$ dari seluruh pemasukkan rumah sakit. Adapun standard pelayanan kefarmasian yang ada di instalasi farmasi rumah sakit adalah pengelolaan sediaan farmasi, alat kesehatan, BMHP dan pelayanan farmasi klinik. Apoteker harus berperan serta dalam pelayanan kefarmasian dan bertemu langsung dengan pasien untuk mendapatkan terapi pasien secara optimal (Lolita, 2019).

Menurut Meity(2019) tentang Analisis Pengelolaan Obat Di Instalasi Rawat Inap Rumah Sakit Jantung Bina Waluya Jakarta Timur Tahun 2019 menyatakan bahwa pengelolaan obat masih belum efektif, hal ini disebabkan masih ada beberapa komponen yang belum memenuhi persyaratan yaitu sarana dan prasarana serta proses penyimpanan yang tidak sesuai dengan Peraturan Menteri Kesehatan Republik Indonesia Nomor 72 Tahun 2016 tentang pelayanan kefarmasian di rumah sakit. Dampak yang muncul dari tidak berjalannya suatu proses manajemen pengelolaan obat akan mempengaruhi kesiapan obat di rumah sakit. Dampak buruk dari tidak siapnya obat juga sangat mempengaruhi penyembuhan pasien dan juga melemahkan mutu terhadap rumah sakit itu sendiri. Oleh karena itu rumah sakit harus sesuai berdasarkan aturan-aturan tentang pengelolaan obat. Selain itu rumah sakit juga wajib mempunyai SOP untuk petunjuk dalam menjalankan pengelolaan sediaan farmasi yang dilakukan oleh instalasi farmasi rumah sakit.

Manajemen pengelolaan obat merupakan salah satu bagian yang memiliki peranan penting dalam berlangsungnya pengelolaan obat yang ada di rumah sakit dan apabila salah satudari proses pengelolaan obat tidak berjalan baik atau mengalami kendala. Maka dampaknya akan menghalangi atau mempengaruhi sistem pengelolaan obat seperti mengalami kehabisan stok obat dan menurunkan mutu kualitas pada Instalasi Farmasi itu sendiri (Permenkes, 2016)

Oleh karena itu hal yang ingin didapat dari penelitian ini adalah untuk mengetahui manajemen pengelolaan logistic obat dari proses Pemilihan sampai Administrasi di Instalasi Farmasi Rumah Sakit Tipe C se-Kabupaten Tegal berdasarkan dengan Petunjuk Teknis Standar Pelayanan Kefarmasian di Rumah Sakit Tahun 2019.

\section{Metode Alat}

Alat yang digunakan pada penelitian ini adalah berupa kuisioner yang dibuat berdasarkan dari pedoman Petunjuk Teknis Standar Pelayanan Kefarmasian Di Rumah SakitTahun 2019 terkait dengan proses manajemen pengelolaan logistic obat sebanyak 45 pertanyaan yang melipui proses pemilihan, perencanaan kebutuhan, pengadaan, penerimaan, penyimpanan, pendistribusian, pemusnahan, pengendalian dan administrasi

\section{Bahan}

Bahan penelitian yang digunakan adalah kertas kuisioner dan bulpoin 


\section{Prosiding Seminar Nasional Kesehatan 2021 \\ Lembaga Penelitian dan Pengabdian Masyarakat Universitas Muhammadiyah Pekajangan Pekalongan}

\section{Metode}

Jenis metode yang digunakan pada penelitian ini bersifat deskriptif kualitatif dengan penilaian kuisioner menggunakan skala guttman dimana penelitan mendapatkan jawaban tegas yaitu IYA atau TIDAK

\begin{tabular}{|c|c|l|}
\hline No & \multicolumn{1}{|c|}{ Rentang } & \multicolumn{1}{|c|}{ Kategori } \\
\hline 1 & $0-20 \%$ & Sangat Kurang \\
\hline 2 & $21-40 \%$ & Kurang \\
\hline 3 & $41-60 \%$ & Cukup \\
\hline 4 & $61-80 \%$ & Baik \\
\hline 5 & $81-100 \%$ & SangatBaik \\
\hline
\end{tabular}

\section{Populasi Dan Sampel}

Populasi pada penelitian ini adalah berjumlah 18 Apoteker dan 24 TTK dari rumah sakit tipe C se-Kabupaten yang meliputi RSU Mitra Siaga, RSUD Suradadi, RSU MKU Muhammadiyah dan RSIA Pala Raya. Adapun sampel penelitian ini adalah Apoteker dan Tenaga Teknis Kesehatan

\section{Uji Validitas Dan Reliabilitas}

Di lakukan di RSUD Kardinah Kabupaten Tegal dengan jumlah smapel sebanyak 30 responden pada bulan April 2021

1. Uji Validitas

Hasil pengolahan data uji validitas yang telah diperoleh dari hasil kuisioner didapatkan bahwa dari 45 pertanyaan berada diatas $r$ tabel $(0,361)$ dengan rentang $r$ hasil yang didapat adalah 0,421-0,802 sehingga dapat disimpulkan bahwa 45 pertanyaan pada pengelolaan logistic obat sudah valid

2. Uji Reliabilitas

Hasil pengolahan data uji reliabilitas pada nilai crobach alpha kuisioner pengelolaan logistic obat didapatkan nilai 0,986. Sehingga disimpulkan bahwa kuisioner pengelolaan logistic obat sudahr eliabilitas karna $>0,06$.

\section{Analisis Data}

Data yang diperoleh kemudian analisis data dengan menggunakan program SPPS versi 23 dan dihitung dengan analisis frekuensi

\section{Hasil dan Pembahasan}

\section{Hasil}

Penelitian ini dilakukan pada tanggal 5 April - 20 Mei 2021 di 4 rumah sakit yaitu RSUD Suradadi, RSIA Pala Raya, RSU Mitra Siaga dan RSU PKU Muhammadiyah dengan pengambilan sampel menggunakan teknik total sampling yang dilihat dari kriteria inklusi dan mendapatkan total responden sebanyak 42 yang terdiri dari 18 Apoteker dan 24 TTK. Analisa yang digunakan dalam penelitian ini adalah analisa univariat dimana dalam pelaksanaanya menghasilkan distribusi frekuensi dari setiap variabel yang diteliti dengan menghitung presentasinya. Berikut hasil distribusi frekuensi yang diperoleh 


\section{Prosiding Seminar Nasional Kesehatan 2021 Lembaga Penelitian dan Pengabdian Masyarakat Universitas Muhammadiyah Pekajangan Pekalongan}

Tabel 1.1 Tabel hasil kegiatan manajemen pengelolaan logistic obat di rumah sakit tipe C se-Kabupaten Tegal

\begin{tabular}{lll}
\hline \multicolumn{1}{c}{ Kegiatan } & $\begin{array}{l}\text { Kesesuaian } \\
\text { SesuaiTidak }\end{array}$ \\
\hline Pemilihan & $100 \%$ & \\
\hline $\begin{array}{l}\text { Perancanaan } \\
\text { kebutuhan }\end{array}$ & $90,5 \%$ & $9,5 \%$ \\
\hline Pengadaan & $71,4 \%$ & $28,6 \%$ \\
\hline Penerimaan & $100 \%$ & \\
\hline Penyiimpanan & $100 \%$ & $12,4 \%$ \\
\hline Pendistribusian & $97,6 \%$ & \\
\hline $\begin{array}{l}\text { Pemusnahan } \\
\text { dan }\end{array}$ & $100 \%$ & \\
Penarikan & & \\
\hline Pengendalian & $100 \%$ & $19 \%$ \\
\hline Administrasi & $81 \%$ & \\
\hline
\end{tabular}

1. Pemilihan

Dilihat dari tabel 1.1 menyebutkan bahwa proses pemilihan obat di Instalasi Farmasi Rumah Sakit Tipe C se-Kabupaten Tegal berjalan dengan sangat baik yaitu 100\%. Berdasarkan dari Juknis RS 2019 tentang pelayanan kefarmasian terkait proses pemilihan obat bahwa Pemilihan berfungsi sebagai kebijakan rumah sakit terhadap penggunaan Formularium Rumah Sakit untuk menggunakan obat yang terdapat pada formularium rumah sakit dengan melihat dan mempertimbangkan berbagai aspek yang berlaku yang disusun oleh Tim Farmasi dan Tim terapi. Selain itu pengajian Formularium Nasional dilakukkan minimal satu tahun sekali.

2. PerencanaanKebutuhan

Dilihat dari tabel 1.1 menyebutkan bahwa proses perencanaan kebutuhan obat di Instalasi Farmasi Rumah Sakit Tipe C se-Kabupaten Tegal berjalan dengan sangat baik yaitu 90,5\%. Adapun hasil yang menunjukkan 9,5\% (responden) yang menyatakan bahwa Apoteker tidak melakukan perencanaan kebutuhan obat berdasarkan waktu tunggu pesanan. Dikarenakan terkadang melakukan pembelian pesanan obat secara online dan terhambat oleh estimasi sedangkan stokobat di IFRS sudah kosong. Adapun langkah yang diambil oleh kepala IFRS yaitu dengan meminjam obat yang dibutuhkan kepada rumah sakit lain karena sebelumnya sudah ada persetujuan untuk itu.

Berdasarkan Permenkes RI Nomor 72 Tahun 2016 Tentang Standar Pelayanan Kefarmasian di Rumah Sakit, perencanaan kebutuhan merupakan kegiatan untuk menentukan jumlah dan periode pengadaan. Perencanaan kebutuhan dilakukan untuk menghindari kekosongan obat dengan menggunakan metode yang dapat dipertanggungjawabkan dan dasar-dasar perencanaan yang telah ditentukan antara lain metode konsumsi, epidemiologi, kombinasi metode konsumsi dan epidemiologi dan disesuaikan dengan anggaran yang tersedia. 


\section{Prosiding Seminar Nasional Kesehatan 2021 Lembaga Penelitian dan Pengabdian Masyarakat Universitas Muhammadiyah Pekajangan Pekalongan}

\section{Pengadaan}

Dilihat dari tabel 1.1 menyebutkan bahwa proses pengadaan obat di Instalasi Farmasi Rumah Sakit Tipe $\mathrm{C}$ se-Kabupaten Tegal berjalan dengan baik yaitu $71,4 \%$. Adapun hasil yang menunjukkan $28,6 \%$ (12 responden) yang menyatakan bahwa pengadaan belum berjalan dengan baik hal ini disebabkan karena belum bisa melakukan pengadaan obat dikarenakan pencairan dana BPJS yang telat karena sebagian besar dari pasien rumah sakit melakukan pembayaran dengan BPJS yang mengakibatkan pihak Rumah Sakit terlambat melakukan pembayaran dengan supplier yang menjadikan rumah sakit belum bisa memesan persediaan stok obat.

4. Penerimaan

Dilihat dari tabel 1.1 menyebutkan bahwa proses peneimaan obat di Instalasi Farmasi Rumah Sakit Tipe $\mathrm{C}$ se-Kabupaten Tegal berjalan dengan sangat baik yaitu $100 \%$.

Penerimaan dilakukan oleh seorang apoteker atau TTK, penerimaan item obat dilakukan dengan pengecekan kualitas dengan melihat organoletik sediaan, tanggal kadaluarsa dan nomor batch yang tertera. Setelah barang pesanan sampai petugas yang bertanggung jawab atas proses penerimaan juga wajib untuk secepatnya memindahkan barang ketempat penyimpanan yang semestinya dan semua dokumen bukti pembelian harus disimpan dengan baik (Juknis RS, 2019)

5. Penyimpanan

Dilihat dari tabel 1.1 menyebutkan bahwa proses penyimpanan obat di Instalasi Farmasi Rumah Sakit Tipe $\mathrm{C}$ se-Kabupaten Tegal berjalan dengan sangat baik yaitu $100 \%$.

Penyimpanan obat adalah kegiatan pengamanan dengan tujuan untuk menjaga barang dengan cara memindahkan barang ketempat penyimpanan yang semestinya yang aman dari pencurian untuk menjaga mutu sesuai dengan persyaratan yang berlaku. Persyaratan yang mencangkup suhu ruang, pencahayaan keamanan, kelembaban dan penggolongan jenis sediaan obat. Proses penyimpanan dilakukan dengan melihat menurut kelas terapi, bentuk dari sediaan yang ditata alfabetis dengan memakai proses FEFO dan FIFO. Untuk penyimpanan sediaan farmasi yang memiliki bentuk visualnya dan penamaannya hamper sama dengan look alike sound alike atau LASA penyimpananya dijauhkan dan diberikan tanda untuk mengantisipasi kesalahan pada saat pengambilan barang (Devi Ristian, 2018)

6. Pendistribusian

Dilihat dari tabel 1.1 menyebutkan bahwa proses pendistribusian obat di Instalasi Farmasi Rumah Sakit Tipe $C$ se-Kabupaten Tegal berjalan dengan sangat baik yaitu $97,6 \%$. Adapun hasil yang menunjukkan $2,4 \%$ ( 1 responden) yang menyatakan bahwa IFRS belum berjalan dengan baik untuk dibagikan ke bangsal-bangsal dikarenakan terkendala oleh persediaan obat (kekosongan) di bagian logistic atau gudang IFRS. 


\section{Prosiding Seminar Nasional Kesehatan 2021 Lembaga Penelitian dan Pengabdian Masyarakat Universitas Muhammadiyah Pekajangan Pekalongan}

Berdasarkan Petunjuk Teknis Standar Pelayanan Kefarmasian Di Rumah Sakit Tahun 2019 menyebutkan bahwasannya untuk memenuhi stok atau jumlah obat yang terdapat pada depo-depo IFRS harus menerapkan salah satu atau kombinasi cara pendistribusian dengan sentralisasi atau dengan pendistribusian desentralisasi. Selain itu, sistem pendistribusian dengan melakukan sistem Unit Dose Dispensing menurut resep perorang yang sudah disajikan dalam depo dengan harapan rancangan tersebut agar tidak menyulitkan dan dapat dijangkau oleh pasien dengan melihat keefektifan dan pemaksimalan SDM yang ada.

7. Pemusnahan dan Penarikan

Dilihat dari tabel 1.1 menyebutkan bahwa proses Pemusnahan dan Penarikan obat di Instalasi Farmasi Rumah Sakit Tipe C se-Kabupaten Tegal berjalan dengan sangat baik yaitu $100 \%$.

Berdasarkan Petunjuk Teknis Standar Pelayanan Kefarmasian Di Rumah Sakit Tahun 2019 pemusnahan dan penarikan sediaan farmasi RS wajib mempunyai program atau alur penanganan obat yang sudah tidak layak dan tidak memenuhi standar yang berlaku untuk digunakan atau ditarik izin edarnya. Dalam proses pemusnahan dan penarikan sediaan obat juga mempunyai alur yang meliputi dibuatkan list nama obat apa saja yang akan dimusnahkan, membuat berita acara pemusnahan, membuatkan jadwal, tempat dan waktu kepada pihak yang bersangkutan dan menyesuaikan jenis atau macam-macam obat apa saja dan bentuk obat sesuai dengan standar yang berlaku.

8. Pengendalian

Dilihat dari tabel 1.1 menyebutkan bahwa proses Pengendalian obat di Instalasi Farmasi Rumah Sakit Tipe C se-Kabupaten Tegal berjalan dengan sangat baik yaitu $100 \%$.

Berdasarkan Petunjuk Teknis Standar Pelayanan Kefarmasian Di Rumah Sakit Tahun 2019 bahwa pada proses pengendalian obat menggunakan SPO yang sesuai dengan ketentuan, melakukan pendataan ulang stock opname yang sudah kadaluarsanya minimal 6 bulan, penerapan tahapan kegiatan pengadaan obat diluar formularium dengan standar Permenkes 16 Tahun 2018 dan apoteker secara cepat melakukan penanganan apabila IFRS terjadi kekosongan obat.

9. Administrasi

Dilihat dari tabel 1.1 menyebutkan bahwa proses pengadaan obat di Instalasi Farmasi Rumah Sakit Tipe $\mathrm{C}$ se-Kabupaten Tegal berjalan dengan baik yaitu $81 \%$. Adapun hasil yang menunjukkan $19 \%$ (8 responden) dimana menyebutkan bahwa IFRS belum mempunyai administrasi keuangan sendiri dikarenakan administrasi keuangan IFRS bergabung dengan administrasi pelaporan dan pencatatan (bergabung) dan belum mempunyai administrasi sendiri. Untuk administrasi keuangan rumah sakit menjadi satu unit untuk memudahkan kebutuhan rumah sakit diantaranya RAB rumah sakit 


\section{Prosiding Seminar Nasional Kesehatan 2021 Lembaga Penelitian dan Pengabdian Masyarakat Universitas Muhammadiyah Pekajangan Pekalongan}

Berdasarkan Petunjuk Teknis Standar Pelayanan Kefarmasian Di Rumah Sakit Tahun 2019 menyatakan bahwa proses administrasi di IFRS meliputi pencatatan, administrasi keuangan, pelaporan dan administrasi penghapusan. Administrasi keuangan yaitu pengaturan anggaran, pengendalian, menghitung biaya, pengumpulan informasil aporan keuangan yang bersangkutan dengan semua aktifitas pelayanan kefarmasian secara rutin, bulan, semesteran atau tahunan.

\section{Kesimpulan}

Hasil penelitian pelaksanaan standard pelayanan kefarmasian terkait dengan pengelolaan logistic kobat di rumah sakit tipe $\mathrm{C}$ se-Kabupaten Tegal dapat di simpulkan bahwa kesesuaian pelaksanaan kegiatan pemilihan, penerimaan, penyimpanan, penarikan dan pemusnahan, pengendalian $(100 \%)$, perencanaan $(90,5 \%)$, pengadaan $(71 \%)$, pendistribusian $(97,6 \%)$ dan administrasi $(81 \%)$ sudah baik sesuai dengan petunjuk teknis standard pelayanan kefarmasian di rumah sakit tahun 2019.

\section{Referensi}

[1] Indonesia, D. K. (2016). Peraturan Menteri Kesehatan Republik Indonesia Nomor 72 Tahun 2016. Jakarta: Kemenkes RI.

[2] Indonesia, D. K. (2019). Petunjuk Teknis Standar Pelayanan Kefarmasian Di Rumah Sakit Tahun 2019. Jakarta: Kemenkes RI.

[3] Key, A. (2017). Manajemen Logistik. Malang: Universitas Muhammadiyah Malang.

[4] Juliyanti, G. (2017). Evaluasi Penyimpanan Dan Pendistribusian Obat di Rumah Sakit Siloam Manado. Universitas Sam Ratulangi, Volume 6, No 4.

[5] Kartika, D. (2018). Analisis Perencanaan Terhadap Kebutuhan Obat Di Instalasi Farmasi Kartika Pulomas. Universitas Respati Indonesia, Volume 2 Nomor $1 .$.

[6] Lolita. (2019). Penerapan Pelayanan Farmasi Klinik Di RSD Ade Muhammad Djoen Kanupaten Sintang Tahun 2018. Pontianak: Universitas Tanjung Pura.

[7] Mahdiyani, C. (2018). Evaluasi Pengelolaan Obat Perencanaan Dan Pengadaan di RSUD Muntilan Kabupaten Magelang. Universitas Fajah Mada, Vol 8, No 1.

[8] Meity. (2019). Analisi Pengellaan Obat Di Instalasi Farmasi Rawat Inap Rumah Sakit Jantung Bina. Jurnal Manajemen dan Administrasi Rumah Sakit, Volume 3, No 2.

[9] Satibi. (2016). Manajemen Obat Di Rumah Sakit. Yogyakarta: Universitas Gajah Mada. 